\title{
Bible translation and gender, challenges and opportunities - with specific reference to sub-Saharan Africa
}

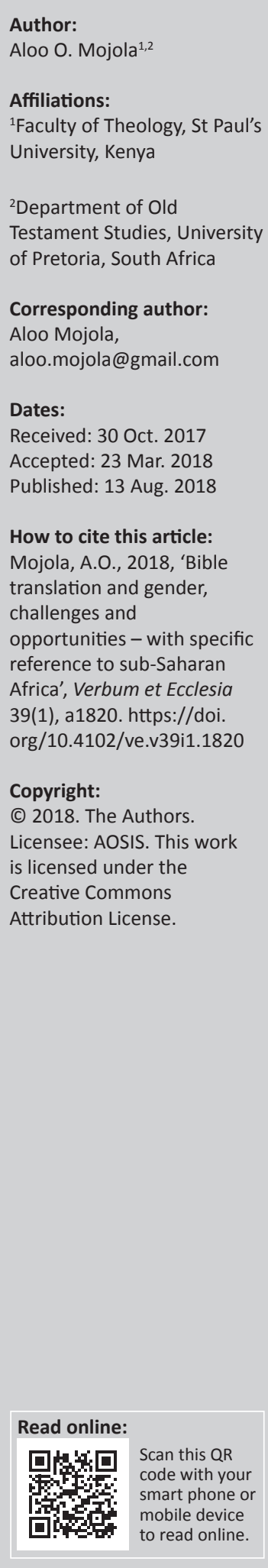

This article focuses on issues of gender in Bible translation and looks at how the dominant patriarchal framework that underlies biblical cultures, including both traditional and contemporary cultures, influences biblical interpretation and ensuing Bible translations in diverse languages. This framework undermines gender-neutral or gender-sensitive interpretations and translations of the biblical text in favour of the dominant patriarchal tradition. Belief in biblical inerrancy and infallibility tends to buttress and lend solid unwavering support to the patriarchal standpoint in spite of the diversity and variety of numerous contested, differing and even opposing interpretations on many key biblical teachings. The article seeks to challenge the role of patriarchalism in biblical interpretation and translation drawing on insights from gender studies, translation studies, biblical studies and cultural studies. It seeks to interrogate the ways in which the Bible is used to defend patriarchalism and to propose a gender-sensitive approach rooted in the principles of justice, fairness and the equality of both male and female as created in the divine image.

Intradisciplinary and/or interdisciplinary implications: This article brings to question basic assumptions on issues of gender in the following disciplines - Biblical studies, translation studies and social-cultural studies - and propose a rethinking of these assumptions and if possible their abandonment and replacement by those that promote egalitarianism and justice across the sexes.

\section{Introduction}

As author, my interest in the subject of Bible Translation and Gender stems from my work in Bible Translation under the umbrella of the United Bible Societies, spanning a period of over 30 years, beginning from 1983 when I stepped down from my work as a lecturer in philosophy at the University of Nairobi, Kenya, to embark on a career in Bible Translation with the Bible Societies in Africa. This required retraining and a serious commitment to study biblical languages and acquire skills in biblical exegesis, historical, social and cultural analysis, literary and discourse analysis and so on. Bible translation, indeed the work of translation in general, is by its very nature an interdisciplinary or cross-disciplinary activity and calling. I spent many years working with Bible translations in the languages of Eastern Africa (Kenya, Uganda, Tanzania, Rwanda, Burundi and Eastern D.R. Congo) as a translation consultant and later as the Africa Translation Coordinator for the United Bible Societies. At the latest count I was surprised to note that I have been privileged to work with or to contribute to midwifing over 60 different Bibles and New Testaments in various African languages. This is humbling and at the same time something for which to thank God. During this period I encountered and grappled with numerous texts that required paying attention to questions of gender and specifically gender in Bible translation, or how gender is handled in biblical texts across languages and cultures - with specific reference to African realities. My involvement as the director of a Kenyan Non- Governmental Organization (NGO), Men for the Equality of Men and Women (MEW), that champions and defends the equality of the sexes has also helped me to appreciate better the importance of gender equality locally and globally.

\section{The power of Bible translation}

The Bible is not always perceived or received in a neutral way. The Bible generates a whole range of complex and often ambiguous attitudes. For some the Bible is perceived as an oppressive tool, a tool that has historically been used to alienate and to dehumanise. It has been viewed as an instrument of empire, of colonial and cultural domination, of conquest and subjugation or as Karl Marx once put it in that memorable phrase, 'the opium of the people'. Not long ago the Bible was 
used by some to provide a basis for the discrimination and oppression of minorities, including women, black people and others. The Bible is obviously not neutral. Its entry into a culture sends mixed and contradictory messages. Where some see loss, others see gain. Where some see dispossession, others see empowerment. Where some see conquest, others see freedom. Where some see foreignisation, cultural dispossession and alienation, others see a call and challenge to reclaim our true humanity, a return to our divine image and values. For the vast majority in the Christian church, the Bible is viewed as a transformative tool-indispensable to the life and work of the church. It is the church's foundational and guiding document, central to the formulation of her creeds and to the formation of her faith and practice, to the fostering and nurturing of just and loving communities. Yet the Bible cannot be understood in a vacuum. It means different things to different people.

Most of us meet the Bible in one or another of its numerous translations. There is of course the original text of the Bible written in ancient languages that are no longer used - 'dead languages', as these are sometimes referred to. As most know, the books of the Christian Old Testament or the Hebrew Bible were originally written in ancient Hebrew - except for parts of the book of Ezra 4.8-6.18, 7.12-26 or the book of Daniel $2.46-7.28$ originally written in the related ancient tongue of Aramaic. The books of the New Testament are on the other hand written in the ancient Greek tongue commonly called Koine Greek because it was the common language, the street language, the market language, the common person's language. The ancient (African) Alexandrian 2nd-3rd century BC translation of the Hebrew scriptures (Biblia Hebraica) commonly referred to as the Septuagint is written in ancient Greek - the imperial lingua franca in the era of the Pax Graeca. The original autographs of this biblical text no longer exist. Extant copies of these have been unearthed or found stored in diverse and various locations of the ancient biblical world. Thanks to the painstaking, patient and demanding labours of textual or text critical scholars, we have a rational basis for believing that current critical editions of the biblical writings are as close as we can get - given the available evidence. Yet these critical editions of the ancient biblical texts remain in the ancient languages, rooted in ancient cultural practices, traditions, belief systems and historical contexts.

The books that make up the Bible were written by a variety of individuals or groups of people over several hundred years and covering a wide range of contexts, periods, people and cultural traditions, as well as linguistic and religious traditions. Moreover, these books get bogged down into thick and sometimes impenetrable layers of both traditional and modern interpretations spanning a wide range of periods Jewish, Christian and secular. The resulting kaleidoscope of meanings and beliefs coexist in unexpected environments and in unrecognisable guises. The challenge posed in deciphering the complexity implied in such a corpus is truly immense. This is a veritable challenge to biblical exegete and translator alike.
Bible translators see themselves as called to provide access to this ancient text. Indeed, without translation, the biblical writings and their rich treasures would remain forever closed and inaccessible to the millions whose lives are touched by them. For the vast majority of people, the Bible that they know and read or hear is a translated Bible - one written in a language that they speak and understand, a domesticated Bible that by means of a translator's mediation has crossed boundaries of time and space, of language and culture, of ancient political, economic, historical and religious environments and formations to those of our own time and place.

To what extent does the Bible in your language or another's language resemble the original one? To what extent is it possible for any translator to recover the original meanings or the message of the ancient text in our modern translations and environments? Is it possible to read this ancient text other than from our own current contexts and in terms of our own interests, ideology and situation? To what extent, then, is translation a betrayal, a rewriting of the text? These and numerous other questions continue to bedevil the modern and postmodern translator.

The imperative to translate the Bible in terms of our language and time, in terms of our own culture and categories is first recorded on a large scale with the (African) Alexandrian Greek translation. This signified a Hellenisation of the faith - a rewriting of the text in Greek terms, in Greek categories, on the basis of the underlying Greek life world and thoughtworld. This was in effect a Greek incarnation - in the era of the Pax Graeca. The next big story was Jerome's Latinisation of the biblical text in the 4th to 5th century AD (331-420) in the era of the Pax Romana. Jerome essentially turned his back on the lingua franca of a former imperial order to that of his own time. His translation was said to be in a vulgar tongue, the language of the street, of the common citizen - hence the vulgate or the so-called Latin vulgate. Latin was yet to become the language of the Church and liturgy - and remained so right to recent times. Those who challenged Jerome's translation were to do so at their peril - among them the renowned John Wycliff (1330-1384) of the Wycliff Bible Translators fame or William Tyndale, who attempted a classic and seminal translation in English. These paid the ultimate price - with their blood.

The proliferation of new translations during and after the Protestant reformation reflected a fragmentation and weakening of the Roman Empire, the Roman Church and the dominant Latin tongue. New empires and tongues were emerging. The influential translation of Martin Luther in German or the so-called authorised King James Version in English in 1611, among others, were a product of this development. The emergence of new power centres and the colonisation of non-Western cultures and people created opportunities for their evangelisation and Christianisation by the emerging Christian powers. This is the wave that launched the Bible Society movement and the era of 
vernacular Bibles in the languages of the peoples of Africa and the southern continents. This development placed Bible translation at the cutting edge of mission, in its role of opening up dialogue with popular cultures, with the idioms and speech of the heart and with inventing and creating the foundations for the language of church, of liturgy and of popular theology. Professor Andrew Walls of the University of Edinburgh, Scotland, in a classic paper 'The Translation Principle in Christian History', points out that (Walls 1996):

Christian faith rests on a divine act of translation - the word became flesh and dwelt among us - (John 1.14). Any confidence we have in the translatability of the Bible rests on that prior act of translation. There is a history of translation of the Bible because there is a translation of the word into flesh. (p. 26)

Seeing translation in these terms underlines the necessity of making Christian discourse and practice deeply rooted in the common culture, in everyday practices of the ordinary person in his or her mundane daily existence. (Walls 1996) writes:

The first divine act of translation into humanity - thus gives rise to a constant succession of new translations. Christian diversity is the necessary product of the incarnation. Translation is by its very nature driven by the twin imperatives of relevance and intelligibility. (pp. 27-28)

Focusing on the positive, we cannot fail to observe the many contributions of translation in Africa, for example. It is thanks to the indefatigable labours of Bible translators that many of our African languages acquired their alphabets or orthographic systems. Among the benefits that accompanied Bible translation, the ones listed below are worth noting (see a discussion of these in Delisle \& Woodsworth 1995):

- the invention of alphabets

- the creation of a literary and a literate class (e.g. in many places the first readers were often Christian; in East Africa Christians were referred to as asomi, wasomi or variants of the same)

- the preservation of languages and development of national languages

- the emergence of national literatures

- the consolidation and propagation of faith

- the writing of dictionaries and grammars

- the transmission of tradition and cultural values

- the revival of languages in contexts where these are threatened or dying

- the facilitation of cross-cultural and intercultural communication

- the critical engagement with certain negative aspects of traditional cultures such as FGM (critique dubbed 11th commandment in the Kenyan Gikuyu struggle against it), killing of twins (Slessor in Calabar) and so on.

It was translation of the Bible into the ancient language of Geez in the 5th to 6th century CE that established the Ethiopic script, literacy and writing in Ethiopia from ancient times to this day. The old scrolls of the biblical text and its interpretation, found in the ancient Ethiopian monasteries in places such as Gondar, Lalibela, Axum and so on, are a testimony to this fact. In more recent times the example of Bishop Samuel Adjai Crowther of Abeokuta, Nigeria, who translated the Bible into his own Yoruba tongue in the mid19th century, shows the role of translation contributing to laying the foundations for the growth of a language. Wole Soyinka, the Nigerian and African Nobel laureate, as well as other Yoruba scholars and speakers, are no doubt indebted to the contributions of Samuel Adjai Crowther. There is no gainsaying the monumental role of Crowther's translation to the Yoruba language and culture. It is comparable to that of Martin Luther's German translation, or to that of the King James Bible translators.

Similarly, the Swahili Bible in East Africa has played the key role of laying the foundations for a standard form of the language. Coinciding with the era of Pax Brittanica, the Swahili Bible and Swahili were assisted by the government enforcement of a standard orthography and lexicon, the turning of Swahili into a school language equipped with standard texts and a publishing house, and its use in the mass media in print and audio. As a lingua franca or trade language of the entire East African region, currently spoken by around 50-80 million people, with nine complete Bibles translated into Swahili and five centuries of written poetry, this language has greatly benefited from the gains that came with Bible translation.

\section{Translation theory and practice}

I first got involved in the world of Bible translation in the early 1980s. This was at high noon of the era of the legendary Eugene Nida, one of my mentors, role models and the most respected translation scholar in the Bible Society movement. He was the leading light and translation theoretician in the Bible Society movement. His ideas still dominate this field, albeit without open acknowledgement. Dr Nida was a great inspiration to me during those early years of my career. From Nida I learnt that translation is a cross-cultural, cross-temporal, cross-world transformational, communicative event. As he put it, it involves 'crossing the same river twice' (obviously quoting Heraclitus 'No man ever steps in the same river twice, for it is not the same river and he is not the same man'). The task of translation calls for the utmost sensitivity and care, in the process of mediating between worlds. Translation is not simply the process of rendering individual words or individual sentences. It involves penetrating the underlying cultural world and experiencing its life world, feelings its rhythms and emotions as well as its values. It involves operating in multiple worlds - primarily the world of the source text and that of the receptor or target text being thoroughly at home in both, commuting comfortably between them. It involves an understanding of these worlds from one's particular vantage point or perspective. It involves interpretive choices influenced by one's values, belief systems, ideological orientation and vocation.

The translator cannot be cut off from his product. The resulting translation has equally as much to do with the complexities of the source text world, those of the receptor or 
target text world, as with the complexities of the person and world of the translator. The translator's invisibility makes us blind to the fact that translators are not value free, ideology free or agenda free. Translators are implicated in all kinds of biases and preferences. The choices they make as they translate foreign language texts reflect their socio-cultural backgrounds, their levels of education, their beliefs and values, their ideological orientation and so on. This blindness leads us to the false assumption that translated texts are objective and unbiased and free from the translator's values and agenda. We do well to remember that (Alvarez \& Carmen-Africa Vidal 1996):

Translators are constrained in many ways: by their own ideology; by their feelings of superiority or inferiority towards the language in which they are writing the text being translated; by the prevailing poetical rules at that time; by the very language in which the texts they are translating is written, by what the dominant institutions and ideology expect of them; by the public for whom the translation is intended. The translation itself will depend upon all these factors. (pp. 1-9)

It clearly helps to know who has translated the text one is reading, including the Bible one is reading, and what their presuppositions and preunderstandings are, what their commitments and agendas are, who commissioned and paid for the translation, what the translation brief was and so on. These factors influence and impact on the nature of the translated text. Some contemporary Bible versions such as the New Living Translation (NLT), New International Version (NIV), New Revised Standard Version (NRSV) and English Standard Version (ESV), among others, make patently clear the translation philosophy underlying the translation and the type of translators who make the translation team, their provenance and their theological position. The translators behind most foreign language texts, including the vast majority of our Bibles, remain anonymous or unknown. They remain invisible. The invisibility of the translator has caught the attention of the American translation scholar Lawrence Venuti (see Venuti 1998 - The translator's invisibility - A history of translation). Venuti is to be commended for highlighting what he refers to as the 'translator's shadowy existence' (cited by Goldberg 1993) and 'weird self-annihilation, a way of conceiving and practicing translation that undoubtedly reinforces its marginal status' (cited by Goldberg 1993). The translator's invisibility is for him 'a mystification of troubling proportions, and amazingly successful concealment of the multiple determinants and effects of English language translation, the multiple hierarchies and exclusions in which it is implicated' (Venuti 1995:16). This is undoubtedly one of the 'scandals of translation' (Venuti 1998), to borrow the title of one of his books.

\section{Translating the name of God across cultures and languages}

As an illustration of the complexity of issues, let me recall briefly an example from the Iraqw Bible translation project that I was involved in a few years ago. The speakers of the Iraqw language live somewhere in the environs of the
Ngorongoro Crater of Northern Tanzania, in the Serengeti ecosystem not far from the famous snow-capped Mt. Kilimanjaro. The problem of translating the name or names of God (the biblical God) in any language confronts the Bible translator right at the outset. The Bible is first and foremost about God and his or her dealings with humanity. One of the first questions for the translator is, how do we translate the name of God in our language? Do we take the path of domestication and use the name or one of the names of God as used in the vernacular or local language? Or do we take the path of foreignisation and borrow the name or one of the names of God as used in the lingua franca or neighbouring dominant languages? Either one of these paths has been taken. Of course, whether a foreign name or a local indigenous name is used, these names are in every case Christianised, which is, understood in Judeo-Christian biblical terms, as interpreted by the theologians or custodians of the true faith or doctrine. However, the choice for the path of foreignisation, or domestication and indigenisation, is not easy. In the case of translating of the name of God into the Iraqw language, we were confronted with the historical, linguistic, cultural and religious reality of a female God, namely Mother Looa. This is the God that the Iraqw people have known across time, the God who appears in their folktales and myths, in their daily talk and conversations, in their traditional and cultural prayers, in their imaginations and thought systems and world views. They have for ages understood the creator of the universe to be Mother Looa. She is the provider and sustainer, the protector and loving mother of all humanity. She is the one to whom everyone runs or calls when they are in trouble. She represents all that is good, pure, beautiful and true. Evil and calamity, suffering and pain are however attributed to Neetlanqw, the male principle. Neetlanqw, interestingly represents chaos, destruction and evil. He is the very antithesis of Mother Looa, the female principle. The Iraqw language refers to Mother Looa using a female pronoun and to Neetlangw using a masculine pronoun. ${ }^{1}$ The translation team was confronted with this reality. Everyone on the translation team naturally settled for Mother Looa. Thus, in the translation of the first book of the Bible, the first chapter and first verse - the Iraqw book of Genesis - the translators did not hesitate in writing that ' $[i] \mathrm{n}$ the beginning Mother Looa created the heavens and the Earth'. The book of Genesis was later printed as a single book for distribution and for testing the translation. For some time we all thought that everything was fine, until the storm broke loose. Some of the Christian leaders thought that there was something wrong. In the Bible as everyone knows God is a father, God is masculine. This is contrary to the Iraqw belief system and world view where, to quote Elizabeth A. Johnson, God is the 'She who is' (see Johnson 1992). To cut a long story short, the masculine God was imposed on the Iraqw translation. The translators, who happened to be mostly female, a Norwegian lady by the name of Froydis Nordbustad, Mary Bura and others were blamed for the decision to use the local

1.The Iraqw language uses grammatical gender as does Hebrew and Arabic, or even English. The Iraqw language belongs to the Cushitic language family, which is part of English. The Iraqw language belongs to the Cushitic language family, which is part of
the bigger Afro-Asiatic language family, of which the Semitic language family is a prominent member. 
feminine name. Theirs was, however, the majority choice. The minority choice imposed by the theologians and some church leaders adopted the name of God as used in the dominant Kiswahili lingua franca, that is, Mungu. However, the problem was that Mungu (also known by such variants as Mulungu or Murungu in related African Bantu languages), although neither he nor she but simply human, was interpreted through the Judeo-Christian masculine lens and understood ontologically and not simply grammatically. I was involved in another translation of the Bible in the Iringa area of Tanzania's Southern Highlands, namely the Kihehe Bible Translation project, where God was referred to as Inguluve. In Kihehe, the local language of this translation, as with all African Bantu languages, there are no pronouns for he or she. Bantu languages only have what are referred to as 'semantic' or 'nominal' classes into which everything falls. Thus, all humans are placed in the people class. ${ }^{2}$ In the traditional Kihehe belief system, the name of God, Inguluve, happens to fall in the semantic or nominal class of things, and thus without any attribution of their nature. The translators decided to change the form of this name from Inguluve (God as belonging to the class of non-human beings) to Nguluve (God as belonging to the class of humans). This placed the name God squarely in the people class and thus conferred personhood to Nguluve. The current ongoing Kihehe Bible translation has thus settled on Nguluve, the God who is personal, and abandoned reference to Inguluve, God as nonpersonal.

In yet another translation with which I am currently involved with, namely the Kenya Ateso Bible translation project, agreement on the name of God has been quite problematic. In an earlier translation, the Uganda Ateso translation Bible, the translation team settled on the name Edeke. This was however mostly used by Protestant Christians. Catholic Christians, who speak the same language and share the same culture, rejected the use of Edeke, whom they understood as some kind of evil being or spirit. The Ugandan Catholic Ateso preferred to use a borrowed name for God, namely Katonda (from the dominant Bantu Luganda lingua franca). In the current ongoing Kenyan Ateso Bible translation project, the translation team have settled on another indigenous name for God, namely $A k u j$, who is also known as Nakasuban. However, Nakasuban is feminine in the traditional religious and cultural understanding. This turned out to be a major problem, given the translators' Judeo-Christian lens. After

\footnotetext{
2.Some 23 or 24 nominal or noun classes, mostly paired and with corresponding Some 23 or 24 nominal or noun classes, mostly paired and with corresponding
semantics, have been identified in this group of languages. The most common and semantics, have been identified in this group of languages. The most common and
ubiquitous noun class (class $1, m u$ ) is singular and is paired with class $2(b a)$, its plural and usually refers to human beings, proper names, kinship terms, personifications. Noun class 7, for example, has the prefix ki- (or variants eki-, chi-, oshi-, tshi-, se-, isi-, $e_{--}^{-}, i_{-}$, etc.) and gives kintu and its variants. Its plural (class 8 ) has the prefix bi- (or its variants ebi-, zi-, i-, zwi-, di-, izi-, etc.), which yields bintu, which means 'things'. However, its semantic content includes body parts, tools, instruments and utensils, animals and insects, languages, diseases and outstanding people. Bantu languages do not necessarily have the full set of these 23 noun classes. Katamba (2003) notes that:

[i]n no single language are all the approximately 24 noun classes reconstructed for Proto-Bantu The highest number of classes retaned by a single language seems to bo-Bantu... The highest number of classes retained by a single language seems to be 21 , as is the case in the Ganda language. Languages with numerous noun classes are said to exhibit the canonical Bantu noun class system, while other with 'reduced' noun class systems have only a rump of the original set... (See my paper Mojola [in press] "The African Bantu concept of Ubuntu in the Christian theology and praxis of Bishop Desmond Tutu of South Africa and its implications for global justice and human rights." ...'.)
}

much discussion, the translation team has with much difficulty transformed Nakasuban (a feminine God) into Lokasuban (a masculine God), with the accompanying use of male pronouns present in the language. ${ }^{3}$ Translation teams in the related and mutually intelligible neighbouring languages of Turkana and Karimojong (in which I was privileged to participate a decade or so earlier) made similar decisions for their Bibles, thus transforming their God from feminine to masculine. ${ }^{4}$

\section{The problem of gender in the Bible}

The problem of translating the name or names of God captures in a very dramatic and vivid manner the problem of gender in the Bible. The first book and first chapter at the first verse confronts the translator with a challenge on how to translate the name of God, with a difficult choice on the question of God's nature and gender. The default position for most translators of the Christian Bible is that God is necessarily masculine, and moreover male, and should therefore be represented or referred to using male pronouns (as required in the case of those languages that have grammatical gender, such as English, where pronouns like he, she or it are used). In the case of languages such as the African Bantu languages that do not have grammatical gender but instead use a system of semantic or nominal classes that are not dependent on gender, the choice is to place God in one of the semantic or nominal classes. The default position is to place God in the 'people' class - which has special markers for persons. Languages with grammatical gender and personal pronouns pose special translation challenges for languages without grammatical gender and personal pronouns. Finding exact equivalents to replace the gendered pronouns is an impossible task. The solution has been to find what Eugene Nida popularised as the 'closest natural equivalent', or as a dynamic equivalent translation and not a formal correspondence translation. Even though the Bible is replete with feminine metaphors or figures for the divine, and in particular for the biblical God, it is the masculine metaphors that are preferred and given prominence. God is clearly not a woman or female, yet an impression is given by translators and exegetes that God is masculine or in the image of the male human being. This in effect is a kind of idolatry because God is not a human being; God is spirit. Our language for talking about God is simply metaphorical, figurative, and symbolic and even anthropomorphic (McFague 1982). Such pictures are often elevated to an ontological status, and the outcome is a reflection of our social ideas, social values and social structures. These pictures, images, figures remain what they are, namely metaphors, ways of speaking, of understanding, of conceptualising. However, they should not be confused with the objective reality they attempt to comprehend.

The biblical perspective is sometimes described as androcentric or sexist and is rooted in a linguistic, cultural and patriarchal scheme or perspective that privileges the male as representative 3.The Ateso uses grammatical gender and thus both male and female pronouns. 4.The Turkana Bible was published in 2000, while the Karimojong Bible was published in 2011. 
of all human beings. It unconsciously promotes the 'belief that persons are superior or inferior to one another on the basis of their sex. It, however, includes attitudes, values systems, and social patterns which express or support this belief' (Johnson 1998). Johnson (1998) notes that '[i]nherited Christian speech about God has developed within a framework that does not prize the unique and equal humanity of women, and bears the marks of this partiality and dominance'.

However, the traditional African perspective is not so. A leading African female theologian, Mercy Amba Oduyoye, succinctly captures the African experience of God with respect to the gender question as follows (Oduyoye 2001):

Most of Africa has no images of God, so where there are no gender specific pronouns it has been insisted that God is supragender. It is also asserted that the God that created males created females, gave both the same spirit and called both human. What is central to our humanity, therefore is that both female and male are akin to God having received the same divine spirit. Gender does not define our worthiness, because it is not present in God. For this reason in the theological writings of African women, the gender of God plays a marginal role. (pp. 42)

\section{She adds further:}

We cannot ignore that fact that while there are many non-gender specific and functional names of God, there are specific male appellations and other references to God that attribute gender, some male, others female. In the end, most African women and men would say that the gender of God is irrelevant to their theology and spirituality. Attributes said to be feminine and others said to be masculine are all applied to God. While there is specifically male and specifically female imagery of the Source Being to be found in Africa, under the influence of Christianity and Islam a patriarchal God has been enthroned, in whose name women who pray to God as 'God our mother' are victimized. (pp. 43)

(This is among the many appellations for and references to God found in Africa, as compiled, for example, by John Mbiti; see his Concepts of God in Africa, 1970).

\section{The invisibility and silence of women in biblical and extra-biblical texts}

One does not need to go very far in a critical and reflective reading of the first chapters of the first book of the Bible to start feeling that the female and feminine has somehow been short-changed. The Creator is declared to be male and masculine, and the ensuing narrative is written and interpreted from a patriarchal perspective. The patriarchal lens pervades and dominates both the Old and $\mathrm{New}$ Testaments. In the Gospels, for example, a quick look at the story of the feeding of the 5000 or $4000^{5}$ confronts the reader with the reality of this invisibility of the woman - present but not counted; present but invisible. An unforgettable and moving American novel that dramatically captures the metaphor of invisibility in relation to humans is Ralph Ellison's classic narrative Invisible Man.
This is not surprising. Susan Ackerman (2016) writes that:

The Hebrew Bible is, in many respects, a man's book. Its authors are arguably all male, and even scholars who point to a few biblical texts that might have been authored by women must admit that these compositions have been transmitted through male scribal communities. The Hebrew Bible's worldview is likewise overwhelmingly male: while Exodus 19:15 is ostensibly addressed to 'all the people', for example, men must in fact be the exclusive audience of the command given there to 'not go near a woman'. The Bible's main actors are in addition predominantly male: the patriarchs of Genesis, Abraham, Isaac, and Jacob; the redeemer Moses, who is the principal figure of Exodus-Deuteronomy; the all-male priesthood that is part of Moses' levitical line; the war leaders of Joshua and Judges; the kings of 1-2 Samuel, 1-2 Kings, and 1-2 Chronicles, along with the prophets of these same books and of the Hebrew Bible's prophetic corpus; the leaders of the postexilic community described in Ezra and Nehemiah; and, according to tradition, poets such as King David (to whom many of the psalms are ascribed) and King Solomon (if one interprets Cant. 1:1 as identifying Solomon as the author of the Song of Songs). Indeed, over 90 percent of the 1400 or so individuals who are given names in the Hebrew Bible are men. (p. 1)

A corollary to the invisibility of women in everyday situations as well as texts including the biblical texts is the silence of women. They are not only unseen but also unheard. Their voices are deliberately or unwittingly suppressed and silenced, marginalised and decentred. The strange thing is that we are not even aware when this is happening. We take it so much for granted, it is the norm! Should we continue to be complicit in perpetuating this injustice?

I found Patricia Madoo Lengerman and Gillian Niebrugge's four basic questions (Lengermann \& Niebrugge 2014) quite helpful and eye-opening, and in some way fine pointers to understanding the reality of the woman question. Starting with the observation that 'women are present in most social situations' and that they usually outnumber their male counterparts, it is intriguing to note that they are deliberately excluded from most social activities that demand leadership or offer social, economic or other advantage. In most cases they are relegated to passive roles, generally side-lined, marginalised, downtrodden, misused, unappreciated, underpaid, overworked, abused, and oppressed and so on. This leads to the first question (Lengerman \& Niebrugge 2014):

[a]nd what about the women? - Where are the women in any situation being investigated? And if they are not present, why? If they are present, what exactly are they doing? How do they experience the situation? What do they contribute to it? What does it mean to them? (p. 441)

The second question: '[w]hy is all this as it is?' Is there something special about males? Is it their biological or physiological attributes? Or is this a reflection on the society that chooses to value the male and devalue the female - a society where the female is invisible, marginal, simply a question of the 'biologically determined attributes associated with male and female' or a result of 'the socially learned behaviours associated with masculinity and femininity' 
normally understood in terms of gender (p. 441)? Why for example are only the male Patriarchs featured? Why only the two sons of Adam? Why the two sons of Abraham? Why the 12 sons of Jacob, why the 12 male disciples of Jesus? Why only male priests? Why are only males counted - as in the feeding of the 5000 and 4000 males by Jesus?

The third question: ' $[a]$ nd what about the differences among women?' Does this have anything to do with 'the invisibility, inequality, and the role differences in relation to men that generally characterise women's lives ...'? Are these not 'profoundly affected by a woman's social location - that is, by her class, race, age, affectional preference, marital status, religion, ethnicity and global location'?

The fourth question: ' $h$ low can we change and improve the social world so as to make it a more just place for all people?' In other words, how do we become agents of change and of transformation, towards a more just and egalitarian society? How do we eliminate or minimise gender inequality and other inequalities?

The above leaves us wondering, 'How - and why does gender inequality persist in the modern world' (p. 442)? In other words, how is it that many very good and well-meaning people, male and female, are blind to this reality and are moreover complicit and active in promoting and defending it? Clearly there is an urgent need 'to rediscover the world' and a deliberate choice to read the scriptures (Lengerman \& Niebrugge 2014):

from the vantage point of hitherto invisible, unacknowledged 'underside' women, who in subordinated but indispensable 'serving' roles have worked to sustain and re-create the society we live in. (p. 442)

\section{The elephant in the room - Patriarchy}

According to Allan G. Johnson (2005):

[a] society is patriarchal to the degree that it promotes male privilege by being male dominated, male identified, and male centered. It is also organized around an obsession with control and involves as one of its key aspects the oppression of women. (p. 5)

A society is male dominated in that 'positions of authority political, economic, legal, religious, educational, military, domestic - are generally reserved for men' (p. 5). It is male identified in that:

core cultural ideas about what is considered good, desirable, preferable, or normal are associated with how we think about men and masculinity. The simplest example of this is the still widespread use of male pronouns and nouns to represent people in general. (p. 6)

A society is male centred, 'which means that the focus of attention is primarily on men and what they do' (p. 10). Another key characteristic identified by Johnson (2005)

an obsession with control as a core value around which social life is organized. As with any system of privilege that elevates one group by oppressing another, control is an essential element of patriarchy: men maintain their privilege by controlling women and anyone else who might threaten it. (p. 14).
Johnson (2005) has succinctly captured the defining elements of patriarchy in terms of 'its male-dominated, maleidentified, male-centered, and control-obsessed character'. He notes that:

At its core, patriarchy is based in part on a set of symbols and ideas that make up a culture embodied by everything from the content of everyday conversation to literature and film. Patriarchal culture includes ideas about the nature of things, including women, men, and humanity, with manhood and masculinity most closely associated with being human and womanhood and femininity relegated to the marginal position of 'other'. It's about how social life is and how it's supposed to be, about what's expected of people and about how they feel. It's about standards of feminine beauty and masculine toughness, images of feminine vulnerability and masculine protectiveness, of older men coupled with younger women, of elderly women alone. It's about defining women and men as opposites, about the 'naturalness' of male aggression, competition, and dominance and of female caring, cooperation, and subordination. It's about the valuing of masculinity and maleness and the devaluing of femininity and femaleness. It's about the primary importance of a husband's career and the secondary status of a wife's, about child care as a priority in women's lives and its secondary importance in men's. It's about the social acceptability of anger, rage, and toughness in men but not in women, and of caring, tenderness, and vulnerability in women but not in men. Above all, patriarchal culture is about the core value of control and domination in almost every area of human existence. (pp. 38-39)

Like all social systems, patriarchy is difficult to change because it is complex and its roots run deep. It is like a tree rooted in core principles of control, male dominance, male identification and male centeredness. Its trunk is the major institutional patterns of social life as shaped by the roots - family, economy, politics, religion, education, music and the arts. The branches - first the larger, then the progressively smaller - are the actual communities, organizations, groups, and other systems in which we live our lives, from cities and towns to corporations, parishes, marriages, and families. And in all of this, individuals are the leaves who both make possible the life of the tree and draw their form and life from it. Obviously, we're in something that's much larger than ourselves, that isn't us. But equally obvious is our profound connection to it through the social conditions that shape our sense of who we are and what kinds of alternatives we can choose from. As a system, patriarchy encourages men to accept male privilege and perpetuate women's oppression, if only through silence. And it encourages women to accept and adapt to their oppressed position even to the extent of undermining movements to bring about change. We can't avoid participating in patriarchy. It was handed to us the moment we came into the world. But we can choose how to participate in it. (pp. 18-19)

The social world and culture of the Bible is undeniably patriarchal in the above sense, as are most social worlds and cultures around the world. A faithful and regular reader of the Bible can hardly fail to see this or gainsay its existence. The African social world and cultures are illustrative of this biblical reality.

Goldberg (1993) defends a theory of male dominance and why men rule or the domination of hierarchies by males. $\mathrm{He}$ argues for the universality of patriarchy, which he defines as 
'any system of organization (political, economic, industrial, financial, religious or social) in which the overwhelming number of upper positions in hierarchies are occupied by males' (Goldberg 1993) and qualifies this thus:

[t]he point is that authority and leadership are, and always have been, associated with the male in every society, and I refer to this when I say that patriarch is universal and that there has never been a matriarchy. (p. 14)

Moreover, to underline his argument that 'patriarchy is universal' he states that ' $[t]$ here is not, nor has there ever been, any society that even remotely failed to associate authority and leadership in suprafamilial areas with male. There are no borderline cases' - that is, 'there has never been a matriarchy ... no society or group anywhere ever associates authority with a female when an equivalent male is available' (Goldberg 1993:15). Goldberg's argument may be historically and empirically valid for most past cases, but the situation is slowly changing. The point is that although this may have been the case and may even be the case in a majority of situations now, it is however not morally right. A theory such as the above is often used to justify the commonplace practice of perpetuating the reality of the invisibility and silence of women. It should be remembered however that what is does not constitute what ought to be. Might is not right. The tyranny of numbers does not constitute a categorical imperative.

Julie Chinwe Ababa (2012), in her paper 'Inequality and Discrimination in Nigeria, Tradition and Religion as negative Factors Affecting Gender'6 (2012:8ff), provides some disturbing details illustrative of gender inequality and imbalance in Nigeria (and glaringly observable throughout sub-Saharan Africa). Her list is spread across seven main areas as follows: (1) education, (2) health, (3) property rights, (4) violence and physical abuse, (5) extreme poverty, (6) a weak economic base, (7) political representation and (8) gender preference. However, she focuses on the cultural domain, where 'women are deprived of basic rights, using culture and tradition to justify the abuse'. Her long list included the following (Ababa:2012):

- Husbands are the Head of the families and their decisions are final. Women must venerate, respect and obey their husbands at all times.

- Most women spend their lives within marriage. They are therefore constructed in the minds of men as dependents and inheritors who need to listen to and follow their spousal leadership and instructions.

- Some educated men have internalized the stereotype that women are emotional and not given to rationality like men.

- Wholesale adoption of gender ideas from fundamentalist religions subordinating women to men.

- In the cultural setting traditional beliefs are strong that for the continuity of the family lineage, preference of male children to females should be encouraged.

- In similar vein, inheritance laws deny females any inheritance, since she is considered to belong to her

6.Presented at the Federation of International Human Rights Museums (8-10 O.ctobe 2012). husband, on marriage. In rare cases, when considered for inheritance, female children get less than their male siblings.

- Early marriages of female children encouraged ...

- Widowhood practices. Most widows blamed for spousal deaths and invariably denied social and economic rights.

- Female Genital Mutilation: Traditionally women play a passive role in sex, her active organ is removed to avoid promiscuity ... She has no right to enjoy sex because her primary role in sexual intercourse is to satisfy her partner and for procreation. (pp. 9-11)

She also lists the effects of gender discrimination on national development:

including lack of decision-making positions as a result of low investment in such sectors as health and education; limitation of women's choices; women's reluctance to take responsibilities; high incidence of insecurity, violence and crimes such as armed banditry, kidnapping, prostitution, child trafficking, cultism; increasing culture of begging because of widespread poverty; inability to access quality health services; large number of school drop-outs resulting from early marriages, early childbirths, poor sanitation and shortage of female teachers; limited contributions to household cash income and limited influence on spending at family level; and the exclusion of women in decision-making roles in our national life, resulting in loss and waste of a vast resource that if well garnered could help situate Nigeria and Africa properly and beneficially in world global systems. (pp. 11-12)

We eagerly look forward to the coming or emergence of a post-patriarchal age (Cooey, Eakin \& McDianiel 1991):

one in which women and men find possibilities for the fullness of life, not through rule over one another, but rather through freedom and mutuality, trust and ecstasy. The mutuality at issue is not between people alone, but between people and other creatures, between people and the earth. It is the fullness of all life, not human life alone, much less male life alone - toward which so many rightly aspire. (p. xii)

\section{Acknowledgements}

The author thanks Dr Mimi Haddad, President of Christians for Biblical Equality, for giving him an opportunity to prepare this paper for the 2017 Christians for Biblical Equality conference in Orlando, Florida, USA. He also thanks Prof. Dirk Human for facilitating publication in Verbum et Ecclesia.

\section{Competing interests}

The author declares that he has no competing interests with regard to the writing of this article.

\section{Funding information}

Prof. Dirk Human, Head of Department, Old Testament Studies, Faculty of Theology, University of Pretoria, South Africa facilitated the publication of this article due to the authors association as Honorary Professor of the Department of Old Testament Studies at the University of Pretoria. 


\section{References}

Ababa, J.C., 2012, 'Inequality and Discrimination in Nigeria, Tradition and Religion as negative Factors Affecting Gender', Presented at the Federation of International Human Rights Museums, 8-10th October.

Ackerman, S., 2016, 'Women in Ancient Israel and the Hebrew Bible', presented the Duke-UNC Consortium for Middle East Studies, Caroline Center for the Study of the Middle East and Muslim Civilizations, 19 September

Alvarez, R. \& Carmen-Africa Vidal, M. (eds.), 1996, 'Translating: A political act', in Translation power subversion, pp. 1-9, Multilingual Matters Ltd, Cleveson.

Cooey, P.M., Eakin, W.R. \& McDaniel, J.B. (eds.), 1991, After patriarchy - Feminist transformations of the world religions, Orbis Books, Maryknoll, NY, p. xii.

Delisle, J. \& Woodsworth, J., 1995, 'Translators through history'. John Benjamins Publishing Company. Amsterdam, Netherlands.

Goldberg, S., 1993, Why men rule - A theory of dominance, Open Court, Chicago, IL.

Johnson, A.G., 2005, 'The Gender Knot - Unraveling Our Patriarchal Legacy, Philadelphia', (2nd edn.) Temple University Press, Chicago.

Johnson, E.A., 1992, She who is - The mystery of God in feminist theological discourse, Crossword Publishing Company, New York.

Katamba, F., (2003) 'Bantu Nominal Morphology' in Derek Nurse and Gerard Philippson, (eds.) The Bantu Languages, Cambridge University, Cambridge, UK.

Lengermann, P.M. \& Niebrugge, G., 2014a, 'Contemporary feminist theory', in G. Ritzer \& J. Stepnisky (eds.), Sociological theory, 9th edn., pp. 440-485, McGrawHill Education, New York.

Lengermann, P.M. \& Niebrugge, G., 2014b, 'Feminism's basic questions', in G. Ritzer \& J. Stepnisky (eds.), Sociological theory, 9th edn., pp. 440-443, McGraw-Hill Education, New York.

McFague, S., 1982, 'Metaphorical Theology: Models of God in Religious Language'. Fortress Press, Minneapolis, MN.
Mojola, A.O., (in press), 'The African Bantu concept of Ubuntu in the Christian theology and praxis of Bishop Desmond Tutu of South Africa and its implications for global justice and human rights', James Ogude (ed.), Indiana University for globa
Press.

Mouton, E., Kapuma, G., Hansen, L. \& Togom, T. (eds.), 2015, Living with dignity African perspectives on gender equality, Sun Press, Stellenbosch, South Africa.

Nurse, D. \& Philippson, G., (ed.) 2003, 'The Bantu Languages', Cambridge University, Cambridge, UK.

Njoroge, N.J. \& Dube, M.W. (eds.), 2003, Talitha cum! Theologies of African women, Cluster Publications, Pietermaritzburg, South Africa.

Oduyoye, M.A., 1995, Daughters of Anowa - African Women \& patriarchy, Orbis Books, Maryknoll, NY.

Oduyoye, M.A., 1996, Hearing and knowing - Theological reflections on Christianity in Africa, Orbis Books, Maryknoll, NY.

Oduyoye, M.A., 2001, Introducing African women's theology, Sheffield Academic Press, Sheffield, UK.

Oduyoye, M.A. \& Kanyoro, M.R.A. (eds.), 1995, The will to arise - Women, tradition, and the church in Africa, Orbis Books, Maryknoll, NY.

Storkey, E., 1995, Contributions to Christian Feminism, Christian Impact, London.

Trible, P., 1978, God and the rhetoric of sexuality, Fortress Press, Philadelphia, PA.

Trible, P., 1984, Texts of terror - Literary-feminist readings of biblical narratives, Fortress Press, Philadelphia, PA.

Venuti, L., 1995, The translator's invisibility - A history of translation, Routledge, New York.

Venuti, L., 1998, The scandals of translation - Towards an ethics of difference, Routledge, New York.

Walls A.F., 1996, The Missionary Movement in Christian History, Mzryknoll, New York: Orbis Books. 